\title{
FUTURE PROBLEMS OF VENEREAL DISEASE CONTROL AFFECTED BY INCREASED TEENAGE POPULATION* $\uparrow$
}

\author{
BY \\ MARTIN B. LOEB $\ddagger$ \\ School of Social Welfare, University of California, Los Angeles
}

Beginning in 1960, the teenage population of the United States will make up about 17 per cent. of the total, and it will climb to 19 per cent. in 1965 and remain there for the more or less predictable future (1980). This is a considerable jump from the 14 per cent. of 1955 . Even more important than the percentage increase is the increase in absolute numbers. The United States of America is having a population surge. Not less than 15 million people will be added to the population in each 5 -year period for the next 20 years. This population increase is not, as in Canada for example, aided by adult immigration but is almost solely the result of reproduction. In other words, most of this increase will normally go through an adolescent phase (Zitter and Siegel, 1958).

Quite apart from the proportions, the absolute number of teenagers is and will be very large. Two other changes in the American population picture are important:

(1) The population is moving from rural areas to urban centres with great rapidity. The bulk of those making this move are in the younger group which includes teenagers and their progenitors.

(2) As a consequence of the move from rural to urban districts, concentrations of population are developing on the coasts. There is, in other words, a centripetal distribution of the population so that we can expect very high concentrations of a young population in the coastal urban centres. This is exemplified by the fact that before long the percentage of persons aged 65 and over in the middle states of

\footnotetext{
* Received for publication March 24, 1960.

+ Prepared for Venereal Disease Section-Western BranchAmerican Public Health Association, San Francisco, June 3, 1959.

$\ddagger$ Director-Santa Monica Teenage Study.
}

Kansas, Missouri, Iowa, and Nebraska will be twice as high as in California and Florida.

In summary then, there are going to be very high concentrations of teenagers in the large urban centres.

Venereal disease is, in a real sense, a social disease, involving not only minimum social contact but maximum moral involvement. This is especially true of the teenager. To emphasize this, when one asks the question of both lay and professional people: "If we had a vaccine for venereal disease, do you believe every child should be immunized?", the responses are generally confused and the answer is frequently "No". Expressed another way, are we going to be able to present a realistic preventive programme to young people in the foreseeable future? I do not think so. Yet the adolescents in our society are increasingly aware of the sexual pleasures, are increasingly stimulated toward sexual activity, and are, for reasons that we can only guess at, interested in living for the present moment. Sexual activity among adolescents will increase. It is possible that this will lead to a greater increase in illegitimacy and in early marriages rather than an increase in venereal disease. One might presume this for two reasons: the first is a consequence of the widespread use of antibiotics which still provide a type of immunity, and the second is that as we see young people to-day there is an interest in more discriminate sexual activity rather than indiscriminate promiscuity.

There is another aspect, however, which may presage a greater venereal disease rate. In so short a presentation it is not possible to back up some of this reasoning in detail, but the chief point is that indiscriminately promiscuous girls are likely to be emotionally sick girls. Most girls get enough satisfaction for their femininity drives without recourse to sexual behaviour (Loeb, 1960). For the most part those who have been deprived of the opportunity to 
learn how to relate to others or who because of emotional disturbances are incapable of relating to others, will resort to indiscriminate sexual relations with as many males as are easily available.

On the other hand, where girls in American culture tend to be able to act out femininity in approved ways, boys have difficulty in expressing masculinity. American cultural patterns for boys lack opportunity for the development of mastery, for risk-taking, for development of the concept of work, and of a sense of career. This means that most boys are likely to become involved in the more primitive forms of masculinity when these are readily available.

With a greater concentration of teenagers in urban neighbourhoods, more boys will have access to the emotionally disturbed, sexually indiscriminate girls. Recently in a large urban centre one such sick girl made herself available to fifteen boys in two sessions, and nine of them contracted gonorrhoea. Had more boys been around she would have serviced them too. There will be many more such sources of infection in the new population concentrations.

The lack of appropriate behaviour outlets and conditions for the development of masculinity also involves some boys in homosexual activities. Homosexuality seems to be due as much to an overemphasis on masculinity as to any assumption of femininity. Homosexual indiscriminacy may well be on the increase.

To sum up the situation of adolescents in the foreseeable future, we can expect to see more sexual interests and great sexual activity in the teenager, but this alone is not likely to lead to an increase in venereal disease. However, the emotionally disturbed girl and the sexually deviant adult will have easier access to larger concentrations of teenage boys who in general lack adequate modes for the expression of their masculinity. This situation will tend to increase the venereal disease rate.

There are several preventive measures which can be taken.

(1) A health education programme could be developed which would fit into the changing sexual mores of our times rather than relying on the traditional moral principles which no longer persist realistically. In our studies we have found teenagers to be avid for discussion with relatively non-authoritarian adults who will listen and discuss rather than preach and punish. The youth-serving institutions and services can properly do this job if and when they see it to be necessary. Parents, priests, and physicians for a variety of reasons cannot do this job adequately because they must take an authoritative view. I am not proposing that we find a substitute for parent, priest, and physician, but I am proposing an additional resource to help teenagers straighten out their problems and positions before they face the discipline-conscious adults.

(2) We ought to try to provide opportunities for the teenage boy to express his masculinity in ways appropriate to modern urban life. This would include less strict age-grading, less supervision, less avoidance of risk, and more opportunities for work and for preparing for career. It might involve the re-formulations of the military service requirements of the Selective Service Act and the over-protective aspects of the Child Labour Laws.

(3) More appropriate mental health facilities can be the most useful part of the preventive programme. If we had good mental health services in our schools to pick out and help those youngsters, especially the girls, who are emotionally disturbed, and to provide adequate treatment, there would be fewer girls seeking some solution to their personal problems by indiscriminate sexual activities (Safier, Corrigan, Fein, and Bradway, 1949).

The intensive case-finding procedures of the public health service could well be enhanced by providing psychiatric care for those who are found to be focal points of infection. For the promiscuous girl or the homosexual, penicillin is not enough.

\section{REFERENCES}

Loeb, M. B. (1960). "Sex Role and Indentity in Adolescence", in "Casework Papers, 1959". Family Service Association of America, New York.

Safier, B., Corrigan, H. G., Fein, E. J., and Bradway, K. P. (1949), "A Psychiatric Approach to the Treatment of Promiscuity." American Social Hygiene Association, New York.

Zitter, M., and Siegel, J. G. (1958). "Illustrative Projections of the Population of the United States, by Age and Sex, 1960-80." Population of the United States, by Age and Sex, $1960-80 . "$
Current Population Reports, Series P-25, No. 187. Nov 10, 1958. Bureau of the Census, Washington, D.C.

Problèmes futures de la lutte antivénérienne, affectée par l'augmentation de la population adolescente.

\section{Résumé}

Dans l'avenir prochain on peut s'attendre à voir plus d'intérêt sexuel et une plus grande activité sexuelle chez l'adolescent, mais ceci en soi-même ne menera probablement pas à l'augmentation des maladies vénériennes. Néanmoins, la jeune fille émotionnellement perturbée et l'adulte sexuellement dévié auront un accès plus facile à des nombres plus grands d'adolescents, qui manquent généralement de suffisants moyens pour exprimer leur masculinité. Cette situation tendra à augmenter la fréquence des maladies vénériennes. 
On pourrait prendre plusieurs mesures préventives:

(1) On pourrait élaborer un programme d'éducation sanitaire qui s'appliquerait aux moeurs sexuels changeant de nos temps, au lieu de se baser sur des principes moraux traditionnels qui ne dérivent plus de la réalité. Au cours de nos travaux nous avons trouvé des adolescents avides de discussion avec des adultes pas trop authoritaires, capables d'écouter et de discuter plutôt que de prêcher et de punir. Les institutions et les services pour les jeunes peuvent bien entreprendre cette tâche si et lorsqu'ils la croient nécessaire. Les parents, le clergé et les médecins ne peuvent pas, pour des räisons différentes, conduire ce travail d'une manière appropriée, parce qu'ils sont forcés d'adopter un point de vue authoritaire. Je ne propose pas le remplacement du parent, curé et médecin, mais une ressource additionnelle qui aiderait les adolescents à mettre leurs affaires en ordre et à prendre leurs positions avant d'affronter les adultes imbus de discipline.

(2) Nous devrions essayer de créer des occasions pour que l'adolescent puisse exprimer sa masculinité d'une manière appropriée à la vie urbaine moderne. Ceci impliquerait des classements moins rigides selon l'âge, moins de surveillance, moins de limites aux désirs de courir un risque et plus d'occasions pour travailler et pour se préparer pour un métier. Cela pourrait impliquer des reformulations des conditions requises pour le service militaire (Selective Service Act) et des aspects trop protecteurs des lois concernant le travail des enfants (Child Labour Laws).

(3) Des facilités plus appropriées pour la santé mentale constitueraient la partie la plus utile de ce programme préventif. Si nous avions de bons services de la santé mentale dans nos écoles, pour dépister et aider ces jeunes, particulièrement filles, émotionnellement perturbés et pour leur donner tout le traitement nécessaire, il y aurait moins de jeunes filles cherchant une solution de leur problème personnel dans l'activité sexuelle aveugle (Safier, Corrigan, Fein et Bradway, 1949).

Les méthodes intensives de dépistage du service publique de la santé pourraient bien être renforcées par des soins psychiatriques pour ceux qu'on considererait des points focaux d'infection. Pour la fille promiscue ou pour l'homosexuel, la péncilline ne suffit pas. 